University of Nebraska - Lincoln

DigitalCommons@University of Nebraska - Lincoln

Publications, Agencies and Staff of the U.S.

Department of Commerce

U.S. Department of Commerce

2010

Fisheries buybacks: a review and guidelines

Dale Squires

NOAA Fisheries, dale.squires@noaa.gov

Follow this and additional works at: https://digitalcommons.unl.edu/usdeptcommercepub

Part of the Environmental Sciences Commons

Squires, Dale, "Fisheries buybacks: a review and guidelines" (2010). Publications, Agencies and Staff of the U.S. Department of Commerce. 316.

https://digitalcommons.unl.edu/usdeptcommercepub/316

This Article is brought to you for free and open access by the U.S. Department of Commerce at DigitalCommons@University of Nebraska - Lincoln. It has been accepted for inclusion in Publications, Agencies and Staff of the U.S. Department of Commerce by an authorized administrator of DigitalCommons@University of Nebraska - Lincoln. 


\title{
Fisheries buybacks: a review and guidelines
}

\author{
Dale Squires
}

NOAA Fisheries, Southwest Fisheries Science Center, 8604 La Jolla Shores Drive, La Jolla, CA 92037, USA

\begin{abstract}
Buybacks of fishing vessels, licences, access and other rights, and gear, sometimes called decommissioning schemes, have traditionally been a key policy tool to address overcapacity, overexploitation of fish stocks, and distributional issues in fisheries. Two more issues can be added, sustainable use of ecosystems and conservation of biodiversity (i.e. ecological public goods and services) and providing a transition to a more rationalized fishery. This study discusses reasons for buybacks; examines consequences; considers asymmetric information, design of buyback auctions and other design issues; buybacks as a transition to a rationalized industry with strong property rights and governance, financing and transnational fisheries; draws out key lessons from the international experience; and provides an overall evaluation.
\end{abstract}

Keywords Buybacks, conservation, decommissioning schemes, fisheries

\author{
Correspondence: \\ Dale Squires, NOAA \\ Fisheries, Southwest \\ Fisheries Science \\ Center, 8604 La Jolla \\ Shores Drive, La Jolla, \\ CA 92037, USA \\ Tel.: + 1-858-546- \\ 7113 \\ Fax: + 1-858-546- \\ 7003 \\ E-mail: dale.squires@ \\ noaa.gov \\ Received 26th Jan \\ 2010 \\ Accepted 5 March \\ 2010
}

$\begin{array}{lr}\text { Introduction } & \mathbf{3 6 7} \\ \text { What is the purpose of buybacks? } & \mathbf{3 6 8} \\ \text { What are the impacts of buybacks? } & \mathbf{3 6 8} \\ \text { Asymmetric information: moral hazard and adverse selection } & \mathbf{3 6 8} \\ \text { Buybacks and conservation of ecological-biodiversity public goods } & \mathbf{3 7 0} \\ \text { Program design issues } & \mathbf{3 7 1} \\ \text { Buyback prices and markets } & \mathbf{3 7 3} \\ \text { Fixed buyback prices } & 373 \\ \text { Auctions to establish buyback price } & 374 \\ \text { Reverse auctions } & 375 \\ \text { Reservation prices } & 375 \\ \text { Available information } & 376 \\ \text { Irrevocable bids and penalties } & 376 \\ \text { Eligibility requirements and scoring or ranking of bids and metrics } & 376 \\ \text { Sealed vs. open bid auctions with heterogeneous bidders } & 377 \\ \text { First- or second-price sealed bid auctions } & 377 \\ \text { Uniform price sealed bid reverse auctions } & 377 \\ \text { Strike price auctions } & 377 \\ \text { Single vs. multiple rounds of buybacks } & 378 \\ \text { Financing buybacks } & \mathbf{3 7 8} \\ \text { Buybacks as a transition to a rationalized fishery } & \mathbf{3 7 9} \\ \text { Buybacks in transnational fisheries } & \mathbf{3 8 0} \\ \text { Guidelines } & \mathbf{3 8 0}\end{array}$




\section{Introduction}

Buybacks of fishing vessels, licences, access, use or other rights, and gear, sometimes called decommissioning schemes, address overcapacity, overexploitation of fish stocks and distributional issues in fisheries (Holland et al. 1999). Additional purposes for buybacks are emerging as fisheries conservation and management evolves, namely as conservation of ecological-biodiversity public goods form an increasingly important complement to the traditional concern with managing a common resource and with the emergence of rights-based management (Curtis and Squires 2007). (Public goods are neither excludable as people cannot be excluded from their use, nor depleted as one person's use diminishes another person's enjoyment.) Buybacks thus increasingly contribute to the sustainable use of ecosystems, the services they provide and contribute to the conservation of marine biodiversity, all of which are public goods. These public goods include marine reserves and fisheries managed to comply with ecosystem objectives. Buybacks also increasingly help provide a transition to a more rationalized fishery based on strengthened property and use rights and stronger private and public fisheries governance.

Most buybacks focus on the vessel, gear and licence, although some buybacks allow the purchase of only gear, such as in the Italian clam (Chamelea gallina, Veneridae) fishery buyback (Spagnolo 2007). A limited number of buybacks only focus on the licences of inactive permits, such as in the New England groundfish fishery (Thunberg et al. 2007).

This study reviews the global experience with fisheries buybacks to develop guidelines and an overall assessment for buyback programmes. The study largely takes the practice of buybacks as a given and as instruments of political economy, and then asks under what conditions are they most effective and how might they be best designed.

This study builds upon Campbell (1989), Campbell and Lindner (1990), Nautilus Consultants (1997), Woodrow (1998), Holland et al. (1999), Weninger and McConnell (2000), Cunningham and Greboval (2001), World Bank (2004), Clark et al. (2005, 2007), Squires et al. (2006) and Curtis and Squires (2007), the latter of which contains three overview chapters (Curtis and Squires 2007; Hannesson 2007a,b; Groves and Squires 2007) plus 13 case studies (Cueff 2007; Fox et al. 2007; Grafton and Nelson 2007; Guyader et al. 2007; Hannesson 2007a,b; Kirkley et al. 2007; Lindebo and Vestergaard 2007; Riechers et al. 2007; Spagnolo 2007; Spagnolo and Sabatella 2007a,b; Sun 2007; Thunberg et al. 2007) presented at the 2004 NOAA Fisheries-University of California San Diego workshop, 'International Workshop on Fishing Vessel and License Buy-Back Programs', plus Organization for Economic Cooperation and Development (OECD) (2009), Martell et al. (2009) and Squires et al. (2010). Many of the existing recent reviews and analyses are unavailable to a wider audience through the peer-reviewed literature, and this study aims to fill this gap. This study also adds additional discussion on asymmetric information between the buyback authority and asset owners and on the buyback markets, especially auction markets, and the price formation process. This review concentrates on key lessons learned: conservation of ecological-biodiversity public goods, asymmetric information issues of moral hazard and adverse selection, design of the buyback market and pricing, other critical design issues, buybacks as strategy and a transitional policy instrument, transnational fisheries, guidelines and an overall assessment. Campbell (1989), Campbell and Lindner (1990), Weninger and McConnell (2000), Groves and Squires (2007), and Martell et al. (2009) address economic welfare, and Weninger and McConnell (2000) discuss investment issues, both of which are not discussed in this study.

The study is organized as follows. First, we discuss the reasons for buybacks discussed in the fisheries literature. Second, we deal with the impacts of buybacks. Third, we introduce the asymmetric information problems that affect buybacks, notably moral hazard, adverse selection, and inefficient vessels known as 'lemons'. Fourth, we discuss buybacks as instruments for conservation of the 
public goods, the ecosystem and its services and biodiversity. Fifth, we tackle design issues. Sixth we discuss the setting of buyback prices and the design of the buyback market. The next section considers the financing options for buybacks. Then, we highlight the importance of buybacks as a transition policy rather than a policy in and of itself. The next following section examines fundamental issues arising for buybacks in transnational fisheries. Finally we provide guidelines and Summary. An Appendix discusses information asymmetry, including principle-agent issues, moral hazard, adverse selection and 'lemons'.

\section{What is the purpose of buybacks?}

Fisheries buybacks address the overcapacity, overfishing and conservation problems that plague many fisheries. The reasons for these problems are open to varying interpretations, which are beyond the scope of this study. The specific fisheries buyback literature identifies at least eight principal and specific reasons for buybacks, not necessarily mutually exclusive. They are discussed by Campbell (1989), Holland et al. (1999), Weninger and McConnell (2000), World Bank (2004) and chapters in Curtis and Squires (2007), and include: (i) directly increasing economic efficiency; (ii) modernizing fleets and adjusting their structure and composition; (iii) facilitating the transition from fisheries with overexploited stocks and overcapacity to private or common rights-based conservation and management; (iv) providing alternatives when rights-based management is infeasible; (v) providing disaster or crisis relief; (vi) addressing compensation and distributional issues; (vii) conserving common resources underlying a fishery; and (viii) conserving biodiversity and ecological public goods.

\section{What are the impacts of buybacks?}

Buybacks generate changes in vessel-level behaviour, both intended and unintended. The changes include: (i) short-run advantages that accrue to vessels remaining in the fleet; (ii) remaining vessels may increase investment or fish longer; (iii) exiting vessels may be the least efficient or fish the least, creating moral hazard and adverse selection issues; and (iv) who gains and who loses, with crewmembers gaining seldom or little.

Attitudes, incentives and cooperation can improve in a transition stage following a buyback. For example, attitudes towards further changes in a fishery improved when the Pacific coast groundfishery was no longer in a crisis stage after buybacks. In this fishery plagued by losses, fishers' attitudes bordered on desperation, incentives favouring cooperation were hobbled and attitudes were noncooperative. Buybacks produced higher profits, or at least more manageable losses, the exit of malcontents and the fewer more committed players remaining facilitated subsequent cooperation. Buybacks restoring profitability gave breathing room to decide further actions and enhance positive economic behaviour, as fishers can behave very differently when in a profitable fishery and with fewer fishers. The fewer players began to coalesce and act like de facto collective owners of the resource. The intention of the Australian southeast trawl buyback included the remedy of the acrimony over the initial allocation and its associated uncertainty and litigation (Fox et al. 2007). The extent to which this experience can be generalized to other fisheries is unknown but important to corroborate.

Over the long-term, higher profits shared over fewer fishery participants, even under a tight limited entry programme, simply encourages additional investment and the adoption of new technology, both of which increase fishing capacity, plus encourage additional fishing, meaning additional utilization of fishing capacity and the capital stock. As a result, profits erode and resource stocks may or may not be reduced, depending on whether or not there are Total Allowable Catches and the effectiveness of compliance and enforcement. This was precisely the case in Australia's northern prawn fishery based on the white banana (Fenneropenaeus merguiensis, Penaeidae), the red-legged banana (Fenneropenaeus indicus, Penaeidae), brown tiger (Penaeus esculentus, Penaeidae), grooved tiger (Penaeus semisulcatus, Penaeidae), blue endeavour (Metapenaeus endeavouri, Penaeidae) and the red endeavour (Metapenaeus ensis, Penaeidae). In this fishery, a series of industry-funded buybacks in conjunction with government loans were required to counter the growing fishing capacity and its utilization (Newby et al. 2004, Fox et al. 2007).

\section{Asymmetric information: moral hazard and adverse selection}

Asymmetric information between the buyback authority (principal) and fishers (agents) in the form of moral hazard and adverse selection can be 
serious issues with buyback programmes. (Moral hazard is a special case of the problem of asymmetric information, whereby the actions of one party to a transaction are unobservable, so that one party in a transaction has more information than another (Mas-Colell et al. 1995). This is discussed further in the Appendix, which also deals with asymmetric information and adverse selection in greater detail. See also Vestergaard (2010). Asymmetric information can be especially important when the buyback authority sets a fixed price rather than the vessel owners through a reverse auction. Buyback markets are prone to these problems, because owners of vessels, permits or gear (agents) are more knowledgeable about performance and characteristics of their assets than is the buyback agency (principal).

During market transactions, the characteristics of goods and services may not be fully observable to all market participants and be asymmetrically held, meaning that some participants hold information that others do not. Thus, the principal and agent may not have the same interests. Similarly during regulation or fulfilment of a contract, an information asymmetry exists between the regulator (principal) who knows less than does the fisher (agent), and this typically leads to economic inefficiency when the fisher circumvents regulations or otherwise does not fully comply with the regulation (contract) (Vestergaard 2010). This inherent information asymmetry and principal-agent problem is the basis for monitoring and compliance. Asymmetric information can give inefficient market equilibriums, resulting in buyback programmes that are not cost-effective.

Moral hazard - incentives to evade contract requirements - can arise when the buyback authority cannot fully observe the actions of vessel or licence owners. Buybacks can rescue unprofitable enterprises, which would otherwise be left to remain or exit the fishery. If the fisher chooses to leave the fishery, his vessel might be sold, perhaps for a substantial loss. With a buyback scheme in place, vessel owners would receive a higher price than they would have expected, given that the buyback scheme will have created an increase in demand and will have raised the expected returns from vessel ownership. Vessel buybacks can signal that capital losses will always be limited, much more so for publically funded buybacks. Reducing the overall risk in the industry encourages risk-averse investors to invest more in fishing boats than they otherwise would. Clark et al. (2005), through a strict version of the rational expectations argument with identical fishers and beliefs, suggest that industry anticipation of publically funded buybacks, especially repeated ones, can lead to vessel acquisitions and greater overcapacity than would otherwise occur. (Rational expectations assume that people make choices based on rationality, available information and past experiences. Forecasts are selffulfilling and policy does not influence people's decisions as it is rationally anticipated.)

Moral hazard may have been an issue in Norway (Hannesson 2007a). Anecdotal evidence suggests that ship owners, realizing potential gains from fleet rationalization, quickly shelved a preliminary plan for an industry-financed buyback when authorities were prepared to use public money for this purpose. In France, fishers have factored into asset values the expectations of future government assistance for leaving the industry (OECD 2009). Fishers have learned to anticipate the buyouts and these expectations have become capitalized in asset values, forcing them up over time.

Adverse selection - targeting the 'wrong' vessels - may arise when asymmetric information exists between the buyback agency and vessel or permit owners. Prior to market participation, owners (agents) have more information about their vessel, permit, intention to fish, and performance in the fishery than does the buyback authority (principal). The level of information differs among participants in these potential market transactions, and costs of acquiring information for the purchasing agency may be high or even prohibitive. Owners know whether vessels require repairs and maintenance, have high operating costs and are less effective at catching fish than other ostensibly comparable vessels.

Adverse selection problems can arise when there are 'lemons'. These are vessels up for sale that are often older, more in need of repair and less productive at catching fish than many other vessels in the fleet. Owners are often older and reaching the end of their careers. Buybacks then simply accelerate the exit of these vessels, which would have left anyway in the near future. Buybacks then increase the demand for vessels and firm up the market, giving the sellers a higher price than they otherwise would have received. In short, there is an incentive for owners of 'lemons' to sell. Evidence suggests that the French buybacks suffered from adverse selection and sales of 'lemons' (Guyader et al. 2007; OECD 2009), as did the Italian Adriatic bottom trawl 
fishery (Spagnolo and Sabatella 2007b). The rate of fishing capacity reduction brought about by the buyback process is less than it would have otherwise been for a given budget, and the resulting fleet tends to be newer and more efficient than would otherwise have occurred without the confounding effect of adverse selection from otherwise exiting 'lemons'.

Owners who are really keen to sell can give away information about their unobservable knowledge through observable actions. A market signal is an action with economic consequences, and the buyback agency's observation of the action may reveal information that is otherwise hidden. For example, a vessel seller could offer to employ a certified marine surveyor to evaluate the prospective vessel and classify the vessel's status. Costless tests could reliably reveal a minimum standard or create a signal such that owners with a vessel of at least acceptable quality will submit to the test, and owners who choose not to submit to the evaluation will be treated as being no better than the worst type of vessel. Because sellers with good vessels are more likely to be willing to take such actions, this offer can serve as a signal of quality, which can lead to a market equilibrium that distinguishes classes of owners and 'lemons'.

Alternative market responses to the problem of unobservable vessel quality and productivity can occur, in which the uninformed party, the buyback authority (principal), take steps to distinguish or screen the vessels on the other side of the market (agents). Buyback authorities can develop mechanisms to allow them to distinguish between vessels or permits of differing fishing power, in other words to identify 'lemons'. Some buyback programmes, notably the one in New England, USA, used a screening approach based on a pricing metric using estimated fishing capacity. Pricing on the basis of physical capacity, such as per vessel, GRT or kW, does not fully capture all of the information of a vessel. Pricing on the basis of revenue, estimated fishing capacity or catch can more closely capture the information on actual and potential catch or fishing capacity.

Adverse selection can be exacerbated when prices offered by buyback authorities are lower than otherwise warranted or expected in comparison with existing second-hand market prices or an expected equilibrium price in the buyback market. Sellers of 'lemons' are far more likely to participate in the market because the buyback price, which may be set at some expected average, lies above what they would otherwise receive on the open second-hand market. Little trade may occur, and the buyback market equilibrium is inefficient. Coordination failure can arise if the buyback authority expects the productivity of vessels accepting a buyback offer to be low and concurrently, the buyback offer price is only accepted by owners of low-quality vessels because the price offered is low. The agency can improve the competitive equilibrium by increasing the offer price. These problems suggest that multiple rounds of pricing or allowing bids in a reverse auction rather than setting fixed offer prices can help set more efficient prices that lead to more costeffective buybacks, especially when the buyback authority sets the fixed price rather than it being established through a reverse auction.

\section{Buybacks and conservation of ecological- biodiversity public goods}

Buybacks are being increasingly used to address the protection and conservation of the public goods created by ecosystems services and of biodiversity (Curtis and Squires 2007). Examples include protecting coral reefs as was done by the buyback of vessels fishing on Australia's Great Barrier Reef, the approach used by The Nature Conservation-Environmental Defense Fund to promote sustainable fishing and the social structure of the fleet along the Central California coast (Groves and Squires 2007), in which fishers can use the purchased licences under specified conditions so that alternative sources of income and sustainable harvesting practices are both insured, and in the buyback applied to the Australian northern prawn fishery to reduce bycatch and protect sensitive sea grass beds (World Bank 2004). Included in the current tworound Australian buyback of statutory fishing rights is the provision for a buyback of vessels and licences from fishers who will be adversely affected by the establishment of several large Marine Protected Areas in the south-east marine region, thereby providing compensation. Another example is the permanent buyback of fishing permits, a temporary leasing back of nets and compensation to fishers in the northern Gulf of California who are willing to switch to alternative fishing methods that exploit new resources that maintain their income but do not cause the endangered vaquitas (Phocoena sinus, Phocoenidae) to be caught at the same time (Barlow et al. 2010). 
Buybacks and replacement of vessels, rights or gears with comparatively more harmful impacts on the public goods of biodiversity and the ecosystem may require additional and ongoing payments to fishers if alternative livelihoods are unavailable or offer lower net benefits (Niesten and Gjertsen 2009). That is, a one-time payment may be insufficient. An example is the replacement of J-hooks by circle hooks in the longline fishery for Latin American mahi-mahi or dolphin-fish (Coryphaena hippurus, Coryphaenidae), which lowered the revenue from the marketed catch even though the bycatch and post-hooking mortality of sea turtles declined, especially of the Pacific leatherback (Dermochelys coriacea, Dermochelyidae). In essence, in this example, the pay-offs to players in an infinitely repeating conservation game, need to exceed direct conservation costs such as new hooks, plus the opportunity costs of conservation. (Opportunity costs are the value of the next best alternative.) This must be true for each time period through the buyback process if incentives are to be restructured so as to favour conservation in the long term.

\section{Programme design issues}

The buyback programme needs to be appropriately designed. This section discusses the 10 most important issues, each of which is stated first in italics.

First, the buyback programme should set clear goals and objectives. There may be conflicting objectives, such as removing fishing capacity and modernizing the fishing fleet, financed by public subsidies. The European Union Multi-Annual Guidance Programs, for example, attempted to simultaneously satisfy the multiple and conflicting objectives of reducing fishing capacity and modernizing ageing fleets (Cueff 2007; Guyader et al. 2007; Lindebo and Vestergaard 2007). In the face of conflicting objectives, narrowing the objectives down to those that do not conflict and to the most important can be expected to enhance programme success.

Second, the buyback programme requires a clearly defined scope. Which gear types and fisheries, vesselsize classes, geographic areas, full- or part-time vessels often classed as being 'latent', commercial or recreational, licences and/or vessels are all questions that arise and which also affect programme size and budget. These strategic choices affect the structure of the post-buyback fishery, cost-effectiveness of the programme, type of incentives that are generated and ultimate programme effectiveness.
Third, there are three critical preconditions that must be fulfilled for an effective buyback programme. (i) Proper registration of licences and vessels creates a well-defined universe of eligible owners and provides well-defined programme boundaries. (ii) Programme organization and communication between regulators and participants and among participants facilitates success. (iii) Without in situ measures to prevent new entry of catching power in place of that removed, funds obtained by fishers from purchased vessels or licences can be used to purchase an upgraded or new vessel, to invest in existing vessels, upgrade technology or can allow new participants to enter. Public funding exacerbates this due to additional, transferred funds. To the extent that fishing asset owners anticipate publically funded buybacks, owners may be motivated to acquire additional assets, even if the prospects of realizing a normal return on their investments is low (Clark et al. 2005, 2007). Many buybacks are increasingly financed by industry rather than by the public, so that what Clark et al. $(2005,2007)$ call the inconsistency problem is likely to be of minimal importance in these instances. To address this in the Italian Adriatic trawl buyback, the Italian government introduced a moratorium on new licences and a limit on construction of new vessels (Spagnolo and Sabatella 2007b).

Fourth, the buyback programme must decide to purchase the capital stock (vessel and/or gear) or the licence, or both. Purchasing only the licence is cheaper than purchasing the vessel and gear, which in turn is generally cheaper than purchasing the bundled vessel and licence. Licence prices may be set at the market rate, although the expectation of increased revenues after a capacity reduction may cause licence prices to rise sharply, or at the value required to encourage the chosen proportion of fishermen to surrender their licences (Read and Buck 1997).

Many vessels hold licences for multiple fisheries and buybacks can create adverse spillover effects. If the programme buys back only the licence, the vessel remains free to fish elsewhere and in doing so may easily shift its fishing capacity to another fishery, whose utilization can even increase with the increased available time. If the programme buys back the vessel and gear but not the licence, the licence, if transferable, can be used with another vessel in the fishery. In this instance, pressures on the fish stocks and economic rents may not be abated, and may even increase if the licence is used 
with a vessel that is even more productive or utilized longer than the vessel that was removed.

Purchasing only the licence frequently removes vessels that are inactive or nearly so, but which could potentially increase their fishing as the profitability of the fishery improves. Inactive vessels or those with low activity may have their primary focus in other fisheries, and hold licences more as options to fish, so that the licence price reflects option value.

Licences can be attached and locked to vessels, precluding the emergence of a separate market for licences. The buyback makes no distinction between the vessel and licence and the buyback price includes the values of two assets. Fishing capacity would not be allowed to shift to another fishery. If a bought-out vessel also held licences for other fisheries and these licences were also attached to the vessel, then the buyback price could include the licence values from the other fisheries and reflect the expected profitability from those fisheries.

Multiple licences for the same fishery may be held with the vessel - or 'stacked'. When licences are attenuated by limits to capacity, stacking then allows a larger vessel or catch. The buyback price can be expected to increase with stacking.

Fifth, the buyback programme can be voluntary or mandatory. Most buybacks are voluntary. One of the few mandatory buybacks programmes was the Northern Australian prawn fishery (Holland et al. 1999). The Japanese longline fishery buyback allowed mandatory participation should there be insufficient voluntary participation (Kuronuma 1997). The buyback programme of high seas longliners in Chinese Taipei was also mandatory (Sun 2007; OECD 2009). In these instances, the thorny issue of determining who must sell has to be addressed. The Italian clam fishery buyback was voluntary, but the programme nonetheless required a minimum number of vessels in each area.

Sixth, the buyback programme should limit reuse of the purchased vessel, gear or licence, with scrapping of the vessel and/or gear or permanent retirement of the licence the best practice, in order to prevent increases in fishing capacity in the fishery of concern or spillovers to other fisheries. Vessels not scrapped can be used in another fishery, therefore transferring the common fish stock and public good externalities to another fishery. Even if a vessel is not transferred, buyout funds might be used to purchase vessels in other fisheries. Some buybacks allow construction of new vessels if the previous vessel is scrapped. The Italian government introduced a moratorium on new licences and limited construction of new vessels in the Adriatic groundfish fishery (Spagnolo and Sabatella 2007b). Some buybacks restrict the use of the vessel or licence in that country, but allow sale abroad as was done in Norway (Hannesson 2007a). This just exports the problem to another country and fishery. The Italian driftnet buyback allowed vessels to convert to another activity or gear. This reconversion into the use of passive gears produced an increase in fishing effort in close proximity to the shore. This area was already exploited by a considerable number of vessels belonging to small-scale fisheries (Spagnolo and Sabatella 2007a). In some cases, vessels might be sold to help finance the buyback as happened in the British Columbia salmon troll buyback (Grafton and Nelson 2007), but this can spillover to other fisheries. A programme that does not require scrapping may have an impact on the price of the vessel to be bought out, and second-hand vessel prices may fall, which becomes a pecuniary externality. (Pecuniary externalities redistribute income through changes in relative prices.)

Seventh, strong conditions should be placed on reinvestment of buyback funds in the buyback fishery to limit reinvestment or new investment. In the Australian South East trawl fishery, the purchase of latent licences, although partially limiting future increases in fishing effort appears to have facilitated additional investment in the same fishery as public funds obtained from the sale of inactive licences were evidently invested by operators in the capacity of active vessels. Ideas must be given to use these funds in spillover fisheries.

Eighth, most buyback programmes entail one-time payments, but some programmes may need recurring payments to cover ongoing opportunity costs and alternative sources of income and livelihood for sellers who are not entirely exiting fisheries altogether, especially when the buyback is oriented to the public goods of conservation and ecosystem services and to developing countries (World Bank 2004, Niesten and Gjertsen 2009). Many buyback programmes in higher income countries effectively accelerate the exit of fishers ready to leave in the near future, either to retire or shift sectors or fisheries, so that one-shot payments suffice with adverse selection. Especially in developing countries or in isolated and marginal areas elsewhere, fishing communities may have limited alternative sources of livelihood and require ongoing buyback payments to create incentives for 
selling and compliance. In effect, the alternative livelihoods along with the buyback payment covers opportunity costs so that no party loses and restructured incentives provide a continuing incentive rather than a one-shot buyback payment with its one-shot incentive. The main problem is that this differs little from an international environmental agreement where all parties must gain (Barrett 2003). Fishers who have been bought out and who have no alternative source of income will stay busy at something. Buybacks of harmful gear and its replacement by more beneficial gear as in the buybacks and replacement of J-hooks by circlehooks in the coastal Latin American swordfish (Xiphias gladius, Xiphiidae) fisheries in the Eastern Pacific Ocean are an example of a one-shot approach. This process also forms a desirable and beneficial Pigovian subsidy and lump-sum transfer for reducing the public bad of a bycatch of sea turtles, so maintaining or even increasing nonmarket economic values. A Pigovian subsidy covers costs external to firms or consumers and helps to provide a socially optimal amount of a public good that is otherwise under-supplied and subject to free riding behaviour. Lump-sum transfers can help insure that an economically efficient Pareto rather than Nash-Cournot optimum (that is economically inefficient and occurs without collective action) is reached.

Ninth, buyback programmes need to consider conditions on fishing time. This is an issue of trade-offs between capital and its utilization and, even more broadly, fishing capacity and its utilization. Buybacks may not only limit allowed fishing time to reduce utilization of all stock inputs, notably the stocks of labour and capital, but also limit the use of variable inputs (for example, fuel) that are closely tied to time. Limits on fishing time attempt to manage the flow of capital services and hence utilization of the capital stock, and fishing capacity in general. When buybacks are a precursor to rights-based management, especially through individual transferable quotas or sector allocations (group quotas) of harvests or fishing effort, then decentralized markets in the former and groups of fishers in the latter address the issue of fishing time; otherwise, the buyback authority should tackle this issue.

Tenth, some buyback programmes set other conditions on vessels and licences that are purchased. Buybacks do not address the underlying property rights issue so that incentives to expand production remain and can even increase if the fishery recovers. In this case, the buybacks can be coupled with other measures to more closely align private incentives with socially desired goals. Buybacks can be tied to quotas as in Norway or to an alternative livelihoods support mechanism (World Bank 2004). Buybacks were tied to the pre-existing ITQ programme in the Australian South East multispecies groundfish trawl fishery (Fox et al. 2007). Buybacks can be tied to gear restrictions, limited access, prohibitions on resale or reuse of vessels, licences, and gear, and cooperative agreements and self-management.

\section{Buyback prices and markets}

Buybacks occur through formal or informal markets during which buyback prices for the purchased assets are set. Four basic systems have been used: one-on-one negotiations, independent valuations, fixed prices and auctions (Holland et al. 1999). Fixed prices and auctions are the two most widely used methods and are less susceptible to collusion and strategic behaviour. Auction design can address adverse selection problems. Competitive bidding can reduce information rents and increase cost-effectiveness but increases transactions costs. Ideally, the auction bid reveals the bidder's true opportunity cost of the vessel, licence or gear, thereby rectifying the information asymmetry. Both fixed price and auction market approaches are examined next.

\section{Fixed buyback prices}

The buyback authority offers a fixed price for the vessel, licence, gear or right, established on the basis of some criteria established by the authority, and the seller of the asset accepts or rejects the price. The fixed price is set on the basis of some metric such as the entire vessel per unit of well capacity, per metre of vessel length or per licence for some vessel-size class. Fixed prices might also be weighted by some criteria, such as in France where the fixed price is weighted according to the fish species targeted by the vessels (Guyader et al. 2007). Martell et al. (2009) discuss several additional approaches. In Denmark, applications for buyback were weighted according to pre-defined categories including age of the vessel, species composition in the catch, the owner's age and days fishing days (Nautilus Consultants 1997). In the Italian clam fishery, buyback the fixed price was calculated on the basis of the market value of the licence (Spagnolo 2007). 
There are advantages and disadvantages to the fixed price approach compared with auctions. Fixed prices provide less information than auctions, as sellers, who are better informed than the buyback authority, do no provide their own offer price and there is less competition and information revealed in setting the price. Fixed prices increase the scope for opportunistic behaviour resulting from informational asymmetries. This approach is administratively easier to establish and less costly to administer than auctions (i.e. lower transactions costs) but is generally less cost-effective at removing capacity than are auctions, because a higher price is paid to owners of 'lemons' and heterogeneous assets than they would receive by an auction in which greater private information is revealed. Thus, the fixed price may bear little relationship to the actual willingness of asset owners to receive compensation for exiting the fishery. When prices are set too low, then some good fishers but predominately owners of 'lemons' leave. Alternatively, when prices are set too high, the programme may cost more to reach its targets than is necessary. It requires the authority to set the price beforehand rather than asset owners setting the price through a decentralized process of competitive bidding or auction that takes into account the private information of bidders. Only when the information asymmetry is not too great and vessels or other assets of concern are relatively homogeneous in value will the adverse selection and 'lemons' problem be limited in scope. When adverse selection is limited and the fixed price comes close to an efficient price, only then will the buyback be comparatively cost-effective in its goal of reducing capacity. A one-shot uniform-price auction and use of the information gained in the bidding process can be used to devise and calibrate an appropriate fixed-price scheme (Latacz-Lohmann and Schilizzi 2005).

The buyback price offered by a particular programme may not equilibrate supply and demand, and the quantity of assets supplied or demanded can exceed or fall short of the funds available. When there is excess quantity demanded or supplied corresponding to the fixed offer price, rationing criteria are required. For example, the Italian Adriatic buyback faced excess supply of licences and prioritized vessels belonging to fleet segments that had still not attained the buyback objective (Spagnolo and Sabatella 2007b). Other possible criteria include primary port or fishing area, vessel-size classes, vessel age, gear type and species fished. The Italian clam buyback, which used a fixed price approach purchased vessels across a range of fishing areas and were chosen by granting priority to those areas where pressure on the resource was highest (Spagnolo 2007). When there is excess demand and not enough vessels or rights to satisfy it, the buyback is no longer voluntary but is mandatory. When there are multiple rounds of buybacks, fewer and fewer fishers may be interested in selling vessels or rights and some form of compulsory criteria are required such as in the Australian northern prawn fishery.

\section{Auctions to establish buyback price}

Auctions are generally more cost-effective than are fixed price buybacks, largely because: (i) more privately held information is established and revealed, where the better-informed asset owners set the buyback price through competition rather than it being set by the less well-informed authority, thereby reducing uncertainty; (ii) there is more competition; and (iii) there is less information asymmetry between the asset owners and the buyback authority. [See Klemperer (2004), Milgrom (2004), Athey et al. (2004), Latacz-Lohmann and Schilizzi (2005) and Whitford (2007), for the theory behind this section.] Auctions help achieve (allocative) efficiency with minimal information required from the agency as the better-informed bidders reveal their privately held information, but transactions costs can be higher. Auction prices are more likely to reflect the fishers' true opportunity costs, reduce price uncertainty, create more competition and reduce information asymmetry compared with a centrally decided fixed price.

All auction formats select the bidders with the highest valuation, so that all auction formats are economically efficient (Latacz-Lohmann and Schilizzi 2005). Thus there is no incentive after the auction to reallocate the traded asset among bidders. None of the losing bidders would be willing to offer a price that would top the winner's valuation.

The buyback authority often compares the auction price to some reference or reservation price to determine whether or not to accept the auction price. Collusion and entry are considerations, and keeping bidding costs low encourages entry and competitiveness of the buyback market. Collusion may be present in buybacks but is seldom discussed or noted. 
There are many different types of auctions. Klemperer (2004) distinguishes ascending-bids, descending-bids and first-price sealed bids where each bidder independently submits a single bid without seeing others' bids, with the sale going to the bidder with the highest bid and the winner pays the highest or first-price. English auctions are ascending bids with open information and Dutch auctions are descending bids with open information. A Vickrey auction or second-price sealed bid occurs when each bidder independently submits a single bid, without seeing the bids of others with the object sold to the bidder with the highest bid. The price paid is the second-highest bidder's bid or secondprice, an incentive-compatible revelation procedure. First-price sealed bid auctions are most common with buybacks. Most auctions in theory provide the same revenue to the bid-taker, known as the Revenue Equivalence Theorem, but are not equivalent in practice (Whitford 2007).

Auctions are usually discriminatory, in which the authority pays each bidder his/her actual winning bid. In a uniform-price auction, all units earn the cut-off price, which is either the highest accepted or lowest rejected bid, and all winners except the one at the cut-off price receives payments higher than the opportunity costs implied in their bids. A bidder's (unique) bid only determines the chance of winning but not the payment received. A bidder's dominant strategy is to bid his/her true opportunity costs. The potential for adverse selection is higher. Buyback auctions have all been discriminatory.

Buybacks invariably employ reverse (supply) auctions that drive prices downward rather than forward (demand) auctions that drive prices upward. Key features include: single or multiple rounds of bidding (single or sequential auctions), open or closed (sealed) bids, rules for determining the winning bidders, potential for collusion, time requirements for preparing and conducting the auction, reserve prices, private value in which each bidder knows his/her value of the object for sale but this is kept as private information, or common value where the actual value is the same for everyone but bidders have different private information about the actual value. There are also revocable or irrevocable bids, penalties for bid defaults, bids responsive or non-responsive to criteria and conditions established, and choice of price metric or weights on bids to achieve different policy objectives. Double auctions, in which the authority (buyer) submits a desired price and sellers submit bids, have not been used. Externalities between bidders are possible if they care about which competitors submit bids. Prohibitive transactions costs can preclude sequential auctions as used for offshore oil leases in the USA.

Kitts et al. (2001) and Bustic and Bromley (2006) econometrically analyse bids in the New England and Pacific coast groundfish buybacks, discuss the bidding process in considerable detail and discuss the econometric issues involved.

\section{Reverse auctions}

Single (simultaneous) sealed bid, reverse discriminatory auctions are the most common form of buyback auction. In a typical programme, the owner of the asset, which can be the vessel, gear or licence, submits a sale offer (bid), which the buyback authority ranks or orders on the basis of some metric such as the highest to the lowest offer price per unit of length, and purchases the lowest, next lowest, bid and so on until the budget is exhausted. The US Bering Sea/Aleutian Island (BSAI) King (red king crab Paralithodes camtschaticus, blue king crab Paralithodes platypus and golden king crab Lithodes aequispinus, Lithodidae) and Tanner crab (Chionoecetes bairdi, and Chionoecetes opilio, Oregoniidae) fishery all employed a first-price sealed bid discriminatory reverse auction. The weighting criteria, such as by catch or revenue history, allows discrimination among different fleet segments (bidding pools) or fishery management objectives.

Bids can be optionally compared with the reserve price established by the authority, purchasing those falling below to insure winning bids satisfy preestablished objectives and reducing incentives for collusion. Multiple round (sequential) reverse auctions can first conduct a single bid reverse auction, but then publicly reveal information from the previous round, and seek revised bids. This approach provides the most information, but entails higher transactions costs and can lead to strategic behaviour by asset owners. Reverse auction winners may be subject to the winner's curse, in which the winner receives less than the losers after underestimating the value of a sold comparable asset, and this may cause everyone to bid cautiously.

\section{Reservation prices}

Reserve prices in a reverse auction are the maximum amount the authority will pay, which can be 
pre-announced or not. The reserve price can be fixed or discretionary (decision to accept is discretionary to the authority). Reserve prices insure against over-payment and, in second-price auctions, they insure that the winner's actual payment is not 'too far' below the runner-up bid, which grows with importance with thin markets (few participants). Reserve prices represent the demand side of the market and the buyback authority's marginal willingness to pay. They are particularly useful if competition is expected to be weak or if collusion and learning is a serious possibility, especially in auctions of multiple rounds, or keeping the authority to a budget, or if bid-rigging is a serious possibility, but they can also limit bidders' participation and reduce bidders' competition. Optimal auction design states that bid-takers should always set reserve prices, set them sufficiently high or low, and never purchase the asset if it fails to make the reserve price. In short, reserve prices are recommended best practice.

The authority's reserve price may be the current or previous years' market prices for second-hand assets obtained from brokers or trade magazines constructed following a formula, or obtained from appraisers. The 1972 British Columbia salmon buyback purchased vessels after valuation by an independent appraiser (Grafton and Nelson 2007). Vessels in the Washington salmon vessel buyback were purchased at an agreed price based on two appraisals by independent appraisers. Licence prices were fixed, and gear was valued at a fixed rate of depreciation from the original cost. One model used was the present value of expected future net earnings plus the difference between the cost of scrapping the vessel and its salvage value (Kitts et al. 2001). Kirkley and Squires (1988) used hedonic regression to obtain expected vessel prices.

\section{Available information}

Fishers formulate bids or accept offers based on their private information and their assessment of the expected or existing bids and valuations of other fishers. Information acquisition affects both the efficiency of the allocation implemented in the auction and the amount of capacity removed by the buyback. Owners hold some private information about the value of their assets, while all potential participants hold some information in common. Information acquisition can be either open or closed; bidders may or may not observe information acquisition by others. Information is a strategic variable when information acquisition is closed. The identity of bidders can affect outcomes, meaning that different information is offered depending on whether the identity of bidders is revealed and who is actually bidding. Buyback authorities also hold information, such as reserve prices, bid discrimination mechanisms, and other factors it values in the auction, and must decide how much to reveal to potential bidders.

Increasing the common information available to owners about what are reasonable expectations if they submit a bid should increase the efficiency of the price discovery process and reduce strategic behaviour and transactions costs, especially in sealed bid auctions. The public authority does not necessarily have to release all available information, but can disclose an average bid price and perhaps available budget, bid discrimination criteria such as price metrics, targeted sectors or capacity target. The less bidders are able to assess the quality of their bids, the more their bidding strategies will be driven by strategic motives and randomness, and the less they will be driven by quality-cost considerations, leading to greater efficiency distortions (LataczLohmann and Schilizzi 2005). The British Columbia experience indicates that release of public information has advantages (Grafton and Nelson 2007). The experimental economics literature shows that releasing individual bits of information does not harm the price formation process. Releasing information may help the process converge to equilibrium, as long as there are enough bidders to preclude collusion. Fishers can practice with computer program of simulated auctions and markets to fully learn the price-formation process.

\section{Irrevocable bids and penalties}

Bids can be specified as irrevocable or retractable where there is an opportunity to reconsider participation as in New England (Kitts et al. 2001). Irrevocable bids militate against speculation, which absorbs considerable sums of money with minimal capacity reduction. Penalties can be imposed on defaulted bids to preclude bidding for options on prizes rather than prizes themselves.

\section{Eligibility requirements and scoring or ranking of bids and metrics}

Price and distribution can be affected by eligibility requirements, bid ranking systems, bid weighting 
criteria and direct allocation of funds among groups (bidding pools). Eligibility requirements are ex ante instruments and bid scoring is an ex post instrument for determining participation. Eligibility requirements can limit the number of participants, opening the way for collusion and strategic behaviour. The scoring or ranking of bids affects who stays and who exits, thereby determining the composition of the remaining fleet, the amount of capacity that is removed or fishery management objectives.

A problem with bid systems involving the sale of a vessel is that everyone offers a different product there is no homogeneous metric and the possession of information is asymmetric (leading to adverse selection and 'lemons'). Use of units of size, revenue or capacity militates against this problem. Licences for a given category of fishing boat or fishery are closer in equivalence than are the vessels themselves and hence easier to judge and require less information.

In ranking bids, consideration can be given to bid discrimination mechanisms, including permit or vessel category, home port, area fished, primary gear, size, length of time in the fishery or any other criterion to target buybacks. Bids with multiple dimensions require weighting. Eligibility conditions and grant size in the Danish buyback depend on vessel tonnage and age (Lindebo and Vestergaard 2007). The Italian clam fishery vessel buyback required a minimum number of vessels to be withdrawn in each fishing area, reflecting the spatial distribution of sessile clams (Spagnolo 2007).

\section{Sealed vs. open bid auctions with heterogeneous bidders}

Sealed bid auctions are less certain to bidders as rival bids are unknown, and tacit collusion is harder as bidding is not used as a signal. Evidence from other industries comparing the effects of sealed and open bid auctions shows that sealed bid auctions attract more entrants, especially small bidders that shift the allocation towards weaker bidders. Revenue is frequently higher with sealed bidding. Calling-out auctions, in which an auctioneer successfully calls increasing bids, are never used apparently with buybacks. These approximate the results of a Vickrey auction (discussed below), as the second highest bidder should stop at his/her willingness to pay. The highest bidder then gets the goods at a cost somewhat higher than this final call. Bidder competitiveness may be an important issue in the choice of format for an auction.

\section{First- or second-price sealed bid auctions}

First- or second-price sealed bid auctions are demand revealing and are mostly used when a unique and homogeneous item is sold, often sequentially if there are multiple units or items. This differs from a simultaneous sale of a group of heterogeneous items such as vessels. In a secondprice reverse auction, which is a form of Vickrey auction, the bidder offering the highest bid wins but only pays the price of the second-highest bidder. Bidders bid their own valuations. Bidding below valuation reduces the chance of winning the auction, as this entails the risk of another participant topping the bidder's bid, and bidding above one's own valuation may increase the chance of winning the auction but in the end paying more than the bidder's own valuation. Bids in the Vickrey auction thus reveal bidders' valuations. Reservation prices that must be paid at a minimum help insure against gross discrepancies in lowest and runner-up bids. In first-price (best and final) auctions, all bidders submit bids, bidders submitting the highest bid win and bidders tend to bid below their true valuation but pay the highest bid. Second-price auctions can be susceptible to collusion. Secondprice sealed bid reverse discriminatory auctions have promise but have not yet been used in buybacks.

\section{Uniform price sealed bid reverse auctions}

In uniform price sealed bid reverse auctions, the winning bids are paid the lowest or second-lowest price actually bid, even if some bids were higher. This type of auction appears to be fair but is vulnerable to collusion and can deter entry into an auction. In a variant, bidders can submit willingness to pay for different quantities sold of a homogenous asset creating a demand function. Uniform price auctions can create windfall rents and are more expensive than other types of auction.

\section{Strike price auctions}

In a strike price auction, fishers submit sealed bids, which the buyback authority weights according to a set of criteria and are accepted until some specified limit of fishing capacity is purchased (OECD 2009). 
This approach contrasts with accepting bids until a budget constraint rather than a fishing capacity constraint is met. All accepted applications are paid the same price as the final accepted (strike) bid. This approach, which provides an incentive to offer a low price in order to be one of the accepted bids, was used in the Northern Ireland buyback programme.

\section{Single vs. multiple rounds of buybacks}

Buybacks can occur in single or multiple rounds but usually in multiple rounds due to budget reasons, including the Taiwan offshore fishery and in Norway (Hannesson 2007a; Sun 2007). Buybacks in stages, which are essentially sequential auctions, have a number of advantages, which are that the revealed common information allows gauging of the bid market and beneficial learning, adjusted payments target particular groups of fishers or desired vessel numbers or capacity level, and the criteria for accepting bids can be adjusted and fishers have the chance to reformulate their bids as they better understand the buyback market and buyback programme. Multiple rounds of bidding also help dampen the frequency of speculative bids.

Buybacks in stages have disadvantages. Prices may increase as multiple rounds progress. With the removal of an asset, supply falls and remaining assets increase in value, partly because fewer assets remain and partly due to gains in rents capitalized into asset prices. There can be strategic behaviour in which the sellers know that they can submit bids in later rounds and may try to increase their bids by delaying. This creates an option, which can be factored into the price. Moreover, repeated buyback programmes can reduce investment risk and thereby encourage excessive capacity. If reservation prices remain fixed, bidders learn more about this price and can insure against bid prices much below the reservation price. Similarly, due to bidders' learning, the average bid in later rounds can closely match the maximum acceptable payment level from preceding rounds, in which case information about the average or the maximum accepted bids or the distribution of bids received in preceding rounds should not be revealed by the authority or auction rules can be varied by round or different groups targeted by round.

Vessel and licence buyback prices may establish a price floor in the second-hand market. Buybacks could announce that the longer the delay the lower the payment in order to reduce the strategic behaviour of vessel or licence owners who delay participation. Multiple rounds can also raise administrative costs.

Availability of funding often determines whether to implement the buyback in one or multiple rounds. Funding may only be available to allow multiple stages. If the buyback is industry funded, do single or multiple rounds better allow the remaining vessels to have the funds necessary to finance a buyback? A single round allows faster recovery of profits and hence the ability to finance. No single approach is necessarily best, but depends on which approach works best in the situation of concern.

\section{Financing buybacks}

Governments have largely funded buybacks but more recently complete or partial private financing has increasingly been used. Public funding may be appropriate initially to correct past policy errors but are effectively government subsidies for improved fisheries performance (World Bank 2004). Mixtures of funding have also been used, combining commercial and recreational fishing interests with public funds as in Texas (Riechers et al. 2007). The US Nature Conservancy (TNC) and Environmental Defense have together funded a buyback of bottom trawlers and permits on California's central coast to protect the ecosystem and its services. NGO or publically funded buybacks to conserve ecosystem and biodiversity public goods can represent desirable and beneficial Pigovian subsidies. (Pigovian subsidies help provide the optimum level of a public good that is otherwise undersupplied due to benefits external to the private provider and free riding. Such Pigovian subsidies are economically desirable, i.e. they are not 'bad'.)

Buybacks funded by industry use income that is expected to rise as the fishery recovers and a public loan can fund the early period of the programme. One option is a 'pay-as-you-go' or incremental approach that purchases assets on an annual basis with funds that are raised each year through an industry levy (Martell et al. 2009). A second, 'big bang' option purchases most or all of the licences immediately using borrowed funds, usually from the public sector. This second approach is the one most widely adopted. A combination of the two is also possible with a single-sizeable buyback in the beginning funded by a public loan and then an ongoing, incremental buyback. Martell et al. (2009) 
observe that the 'big bang' approach is more desirable from a stock-rebuilding and long-term economic perspective compared with the incremental approach.

The buybacks in the US Pacific coast groundfish trawl fishery, the BSAI crab fisheries off Alaska, the Australian northern prawn fishery and buybacks in Iceland under the management programme of individual transferable quotas provide examples in which a landings tax, licence fee or charges on asset values finance the public loan repayment. The public bears a substantial portion of the risk generated by the loan. The debt obligation of a commercial or recreational fisher-financed buyback becomes collective rather than individual and spreads the risk among those remaining. Payment can be apportioned as the relative share of total economic value: commercial interests pay according to their share of economic rent; recreational anglers fund the share of indirect use values; the public and NGOs fund the share corresponding to existence and indirect use values of environmental public goods. Partial or full commercial and recreational fisher financing of buybacks can be justified to the extent that benefits are realized in markets or pertain to direct and indirect use values with the ultimate burden shared between industry and consumers according to the relative elasticities of supply and demand.

Private financing also helps to counter any moral hazard issues that arise when the public sector effectively provides a publically funded insurance scheme to protect against worsening conditions in an industry. This moral hazard is aggravated when the industry anticipates public funding (assuming rational expectations), especially with multiple rounds of buybacks (Clark et al. 2005, 2007). Private financing may be initiated by public loans, especially in initially depressed fisheries. Public and NGO financing of buybacks is economically justified to the extent that benefits are non-market and pertain to public goods such as benefits to the ecosystem or biodiversity, or benefits satisfy social and political objectives, which are often distributional.

Public-financed buybacks where the money is raised by a tax levied elsewhere in the economy can also generate a dead weight loss in consumer and producer surplus or net national benefits. A privately funded buyback financed by a tax levied on landings or a lump sum provides the additional benefit of a Pigovian tax because it compels fishing firms to confront or internalize at least some of the external cost that arises through the resource stock externality. (A Pigovian tax is a tax on costs external to the firm or vessel with a goal to internalize these external costs on consumers and producers. A lump-sum tax does not change behaviour at the margin.) This lastly establishes incentives that favour sustainable harvests of the resource stock. Such a Pigovian tax does not generate a deadweight loss compared with a typically sales or income tax, which lowers social welfare, and instead raises social welfare by reducing and internalizing external costs.

\section{Buybacks as a transition to a rationalized fishery}

The real importance of buybacks occurs when they create a transition to a rationalized fishery based on strong and enforced individual or group rights on catch, bycatch and, to a lesser degree, on one or more of the components of fishing effort, the inputs, and enhanced private and public governance. Buybacks especially as an instrument of political economy create a window of opportunity to transform behaviour by making cooperation among fishers a dominant strategy and to align more closely private incentives with social goals and objectives. Buybacks are thus a strategic choice that restructures incentives. Buybacks can also address the problem aggravated by creation of marine reserves that simply move displaced vessels onto other fishing grounds, thereby aggravating what is typically a pre-existing problem of overfishing and overcapacity.

When fisheries are mired in debt and without profits cooperation is difficult to achieve among players. This non-cooperative behaviour is brought about by individual exceptionally high discount rates, especially under regulated open access, where vessel owners scramble to cover vessel mortgages, keep crews employed and together and cover operating costs. Restored profitability creates incentives for cooperation. Compensation to potential losers or immalleable capital with low opportunity costs (capital with limited alternatives) remove potential blockers of rationalization.

Removing redundant capital with few alternatives for its redeployment accompanied by low opportunity costs leads to the faster removal of excess capacity (Newby et al. 2004). With fewer players remaining there is the potential for cooperation to increase and so ease the establishment of rights-based management. Those fishers remaining 
are those most committed to the fishery further strengthening incentives for cooperation. Australia, New Zealand, the BSAI crab fisheries off Alaska, and the USA Pacific Coast groundfishery all employed this strategy before instituting individual transferable quotas. The Italian clam buyback was a precursor to a self-managed allocation of vessels within the sector, which is a form of group use rights.

\section{Buybacks in transnational fisheries}

Buybacks in transnational fisheries have been used in the Italian swordfish fishery (Spagnolo and Sabatella 2007a) by members of the Organization for Responsible Tuna Fishing (OPRT) for longline tuna vessels, and the Government of Chinese Taipei for its high seas longline fleet (Sun 2007). Although buybacks are often instituted to address the resource stock externality arising from incomplete property rights and sometimes public good externalities, transnational buybacks must also address the transnational externality in which multilateral cooperation is required. [A transnational externality arises with shared or transboundary resources in which the outcome that any one country can realize depends not only on its own actions, but also on what others do (Barrett 2003).] Thus, unilateral buybacks face a free-rider problem in which states that do not fund and participate in a buyback scheme enjoy any resulting benefits without bearing any of the costs; the Italian swordfish fishery faced this issue (Spagnolo and Sabatella 2007a). To varying degrees, all of the transnational buybacks mentioned above ran into this problem. In a broad sense, a transnational buyback needs to be selfenforcing. That is, there is no third party to enforce the buyback agreement. The buyback ultimately rests upon the voluntary agreement to participate by nations, such as the members of a Regional Fisheries Management Organization, members of the OPRT, or signatories to other treaties and agreements.

Limited entry is especially important with transnational fisheries. Without an end to free access, buyback gains can easily be eroded but limited entry in these fisheries is difficult to achieve (Hallman et al. 2010).

Compliance in a transnational buyback can be more complex than in a domestic buyback due to national sovereignty and the ease of entry into most transnational fisheries. Enforcement provisions for a buyback require special consideration. One possi- bility is a requirement that each of the parties adopt domestic legislation supporting the buyback. Domestic legislation is easy to observe but of course enforcement can be another issue altogether. Trade and port measures may be required for enforcement.

Buybacks may be critical to the implementation of rights-based management in transnational fisheries. An especially problematic hurdle to limited entry in transnational fisheries is the initial allocation. In order to achieve limited entry with multiple states, which is a form of multilateral cooperation, especially when there are developing country coastal states and distant water fishing nations, an 'over-allocation' of harvest or effort rights may be necessary so that all parties ostensibly gain (This is actually a side payment from reduced future benefits.). An example is the capacity programme of the Inter-American Tropical Tuna Commission, which limited the total well capacity of tuna purse seiners and allocated shares among countries. Some developing country coastal states may receive an allocation, even though they currently do not have a fishing fleet, effectively receiving an option. Buybacks can then be used to reduce the overcapacity. Financing can be through a tax on landings of developing and developed vessels alike.

\section{Guidelines}

This review of buybacks offers specific guidelines based on best practices from around the globe and from information in the literature.

1. Preventing overcapacity, overfishing and ecosystem and biodiversity degradation before the event is far easier and cheaper than reducing once the fishery has become well established.

2. Buyback design is a strategic choice affecting incentives and potentially plays a strategic role in a transition to a more rationalized fishery based on rights-based management and strengthened governance. Rights can be individual or group and on catches or on fishing effort. Buybacks potentially restructure incentives and relations among participants through improving the economic conditions during a window of opportunity following a buyback. Buybacks potentially restructure fisher strategies and behaviour encouraging a shift to cooperation and hasten restructuring and rights-based management. As buybacks do not change the underlying property rights, long-run 
incentives remain to over-invest in an open or limited access fishery and can even be strengthened by growing profits that eventually overwhelm the positive but temporary economic incentives created by buybacks. In short, buybacks create a window of opportunity to rationalize a fishery that erodes over time.

3. Buybacks are more effective at reducing fishing capacity when fleets are smaller in number, the fishery is well defined, fleet participants are more homogeneous and the fishery is profitable. All of these factors increase the incentives to cooperate. Buybacks can become expensive and costs rise over time as the fleet becomes smaller, resource stocks recover and become more profitable, and there is growing risk that their cost can exceed the benefits gained.

4. Buybacks can be broad but shallow with inclusive eligibility or narrower but deeper, focusing on a particular group or fishery segment. Every one of these choices is a strategic choice that affects incentives and hence behaviour, and shapes the type and structure of the post-buyback fishery. Costs and the buyback market are also affected by the breadth and depth of the buyback.

5. Each buyback design has distributional implications, creating a strategic and distributional choice, as well as being an issue for economic efficiency. There may be equity-efficiency tradeoffs to consider. Buybacks that provide benefits that are uneven throughout a community or area may not necessarily restructure incentives of all the players that are required to achieve cooperation and the overall objective. Most buybacks ignore crewmembers but a few offer compensation to exiting crew. Remaining crew can be expected to enjoy higher returns from a more profitable fishery and the transfer of funds to the fishery if a publically funded buyback.

6. Several preconditions are critical including boat registration and limited access.

7. Buybacks work best through co-management, which affects the strategic choice of the programme design and participant incentives. Stakeholder involvement in all phases from programme design through to its execution strengthens cooperation during the buyback and in the subsequent restructured fishery.

8. Moral hazard and adverse selection arise due to information asymmetry between the buyback agency and fishers. Purchased vessels can be 'lemons', that is, older and less productive than the remaining ones. Buybacks may accelerate the departure of marginal vessels that would not otherwise have left but at a higher purchase price and with little improvement in economic performance and stock recovery. By absorbing risk and establishing a vessel or licence price floor, thereby creating moral hazard, buybacks may strengthen investment incentives for the remaining vessels.

9. There is often no single best answer to many programme design issues. Nonetheless, clear objectives and a clearly defined scope of the programme are critical. A pilot programme can also be helpful. One or more champions can play an important galvanizing force.

10. Decisions must be made to first purchase active or inactive vessels and whether to purchase just vessels or permits or both. No especially clear answer to the sequence seems to exist, although buying out inactive licences first, while the fishery's profitability is limited, may ultimately prove more cost-effective. Otherwise, inactive licence prices rise in value as the supply of licences is reduced and any rising rents are capitalized into licence prices.

11. Buyback beneficiaries can contribute to the funding of the programme in all or in part. Commercial fishers can enjoy increased profits, recreational anglers can benefit from higher catch rates, and the general public and NGOs enjoy strengthened ecosystem health and biodiversity - non-market benefits from public goods. The initial funding, especially for unprofitable fisheries, may be government or an international organization for transnational fisheries.

12. The net economic benefits of buybacks, particularly if public-funded, should be compared with net benefits that could be generated by these funds in their next best use elsewhere in the economy, by the size of the benefits from the buyback in comparison with the programme expenditures and whether there are positive net benefits to society and not just recipients. All of these factors pertain to the size of the opportunity cost.

13. Partial or completely private-financed buybacks may be preferred to full public-financed buybacks because the levy for private funding creates a Pigovian tax that helps to correct the common resource and public good externalities as well as fund the buyback. Lump-sum Pigovian taxes do 
not alter fisher behaviour at the margin but taxes on landings do. Depending on the incidence of the tax between consumers and producers, there may be incentives to curtail fish consumption as consumers do not currently bear their share of the full costs of fish consumption. Privately financed buybacks force industry rather than the public to bear any potential moral hazard, i.e. risk and costs from expectations of future bailouts and strengthened secondary markets and help militate against expectations of future buybacks that can lead to additional investment. Privately financed buybacks are consistent with the concept of beneficiary pays and are not a subsidy.

14. Buybacks can establish fixed prices or auctions. Auction markets are more efficient in terms of allocation and give greater cost-effectiveness than markets with fixed prices established by the buyback authority: when the authority has little information about asset prices, the larger the number of participants, the more heterogeneous the assets, and the more narrowly focused the buyback programme objectives. Bids can proceed in single round or multiple rounds with advantages to each but are usually multiple (sequential auctions) due to limited budgets, although when bidders have the opportunity to learn from preceding bidding rounds, they will use that information to update their bids and obtain higher prices, thereby potentially lowering auction performance through strategic behaviour. Bids are typically first-price sealed bid reverse discriminatory auctions, with prices often weighted on the basis of one or more metrics, including price per metre/estimated capacity/revenue/catch, sometimes by category of fleet or different bidding pools. Eligibility requirements and bid discrimination mechanisms, such as weights for different criteria, are ex ante and ex post instruments to determine bidding pools (fleet segments) and implement fishery management objectives. Irrevocable bids prevent speculation and penalties-less option taking. Providing common information helps form bids and market efficiency but can allow for strategic behaviour from bidders. Auction bids should be compared with reservation prices established by the buyback authority. When the price does not clear the market with fixed price buybacks, the excess quantity demanded or supplied requires a rationing process based on some form of criteria and weights for each criterion. Auctions entail higher transactions costs and less transparency than fixed price schemes, and upfront fixed costs can deter fisher participation. The ultimate purpose is to achieve the objectives at least cost. In sum, the choice between fixed prices and first-price sealed bid reverse discriminatory auctions depends on circumstances, with the latter generally more common and preferred with sufficient numbers of participants; reservation prices should be used with the latter.

15. Selective buybacks can help achieve social objectives other than efficiency and resource conservation goals including the accommodation of new entrants or coastal states, aboriginal rights and shifting capacity regionally, by gear or set type. These are effectively issues of distribution. Funding for these objectives is more complex than simply calling it undesirable subsidies. Buybacks differentially impact gear types or regions but maintaining an equitable allocation of harvests among gear types or regions helps ensure political support.

16. Buybacks increasingly address the under-supply of public goods of ecosystem and biodiversity health and the over-provision of their decline, which can be labelled as public bads. Buybacks can compensate fishers for loss of historical use rights when they are no longer able to fish in marine reserves for example, or they may compensate fishers for methods that reduce bycatch. The gains in non-market existence, option and indirect use values must be weighed against the opportunity cost of public funds used for financing, by the foregone use values for producer and consumer surplus and whether compensated vessels exit the fishery or merely fish elsewhere. Public payments to increase the supply of public goods or reduce public bads contribute to economic efficiency as Pigovian subsidies and can be viewed as increasing welfare and desirable. Buybacks addressing public goods may require ongoing benefits, either directly or for alternative sources of livelihood or to compensate for reduced benefits for fishing communities with limited alternatives, especially in isolated or developing areas.

17. Transnational buybacks require multilateral cooperation and self-enforcement. Unilateral buybacks face failure. New entrants and nonparticipating free riders must be deterred and compliance achieved, which requires changes 
in, at a minimum, customary international law and requires credible trade and port measures for enforcement. Allowing capacity to transfer among individual owners rather than between flag states increases efficiency (Hallman et al. 2010). Coastal states are typically accommodated in initial allocations for growth, a side payment from the future, and the resulting overcapacity can be ameliorated through an industry-financed landings tax that finances a buyback. In some instances, publically financed buybacks to address the transnational externality with transboundary common resources and public goods are called for, depending on ownership of the property right.

18. Buybacks alone are not the long-term solution to the overcapacity and the problem of overfishing the commons in an open-access or limited access fishery. But buybacks may be the best option for transnational fisheries given the limitations of international law for rights-based management protected by a strong international treaty.

19. Buybacks address the capital stock and only indirectly the relationship between inputs and catches and capital and capacity utilization. Unrestricted inputs can be substituted for restricted inputs, capital and capacity utilization can increase from fishing longer, and new technology can be adopted. Vessel buybacks unaccompanied by comprehensive use rights generate incentives for continued investment, overcapacity and overfishing, which are aggravated by public financing. Such expansions in investment and the use of inputs when buybacks are unaccompanied by strong rightsbased management and governance would have to be (imperfectly) countered by an ongoing buyback.

20. Buybacks should be evaluated to identify lessons learned that help improve future programmes (GAO 2001).

\section{Summary}

Buybacks of vessels, licences, gear, access, and other use and property rights can be a useful policy tool of political economy under certain conditions and for a limited time before the benefits erode. Buybacks are not a narrow economic efficiency tool, panacea, or long-term answer by themselves to the commons problems of overcapacity and overfishing or to the growing public bads problems of biodiversity loss and ecosystem degradation. Buybacks are not a first-best policy instrument. (A first-best policy is the most economically efficient instrument that addresses the problem in question.) Instead, buybacks can be viewed as a second-best policy and instrument of political economy although there are firstbest exceptions such as the buying back of harmful gear and its replacement with biodiversity friendly gear (which addresses external benefits and undersupply of public goods and over-supply of public bads). Evaluating buybacks solely on narrow grounds of economic efficiency and first-best policy instruments blinds the user to their potential applicability as a tool of political economy facilitating the realities of implementing accompanying rights-based management and changing behaviour from non-cooperative to cooperative. These are the reasons that buybacks are widely used prior to implementation of rights-based management and the conservation of environmental public goods and where public financing is justified on social or economic grounds.

Buybacks are widely used for reasons of political economy and given this orientation the focus of this study is largely on the most economically favourable conditions for their use. Once chosen as a course of action, how can buybacks be most effectively designed and implemented? Although buybacks are decidedly a second-best policy on the basis of strict economic efficiency, they may be one of the only feasible options for transnational and some other fisheries or for social issues such as compensation, disaster relief, aboriginal rights, and distributional issues and public goods. These are all areas where traditional first-best economic policy instruments have less sway.

Notably, buybacks create a window of opportunity that can provide a limited period of transition to a rationalized fishery based on rights-based management and improved private and public governance, as in Australia, New Zealand, and parts of the USA. Rights can be individual or group and on catch or fishing effort. Even after strong rights-based management with improved governance or other policies have been instituted, buybacks can facilitate exit from the fishery that has become sluggish or correct for allocation conflicts, as in Australia and Iceland. At a minimum, a buyback needs to be coupled with limited access, the scrapping of purchased vessels, limits on reentry through purchases of formerly inactive licences by owners who have just sold an active licence or reinvestment in the 
capital stock, co-management through partnership with industry and effective management of the fishery. Private financing is preferred, possibly kickstarted through a public loan, and can provide a 'double-dividend' Pigovian tax preferably set at the margin.

Buybacks by themselves do not resolve the inconsistency between private fisher incentives and social objectives created by incomplete use or property rights, public goods, inadequate governance, uncertainty and other factors. Simply put buybacks do not directly address these root causes of the 'Tragedy of the Commons' and without otherwise concomitantly addressing these root causes buybacks can even aggravate the situation.

Gains from buybacks alone are transitory. Unless specific steps are taken previously inactive or low activity vessels and permits will activate, investment will continue, new technology will be adopted and the gains from the buyback will erode. Continuous, ongoing buybacks (or other, complementary payments) and automatic attrition through reductions in some specified amount of vessel capacity units with every vessel transfer would need to be a permanent feature. However, such continuous structural adjustment inevitably fails to counter the ongoing increases in fishing capacity as fishers invest in their capital stock, increase capital and capacity utilization by fishing longer, and adopt new technology driven by the incentives of incomplete property and use rights, inadequate governance and uncertainty over the longer term.

In principle, private and public benefits combined should be weighed against the opportunity cost associated with the alternative use of funds and any deadweight losses from taxes not specifically levied to finance the programme to determine whether or not there will be a positive net economic benefit to society. Such a cost-benefit assessment would have to be conducted in conjunction with any complementary conservation and management measures that are undertaken, such as the introduction of rights-based management or marine reserves.

In sum, buybacks by themselves are not usually a first-best policy or a cost-effective way to rationalize a fishery, and by themselves they fail to rationalize a fishery over a longer time period because they do not address the underlying root causes of the commons problem or the collective action problem and under-provision with public goods. Instead, buybacks largely provide a second-best policy and instrument of political economy for the fishery manager that creates a window of opportunity to pave the way to individual or group rights on catches or effort, strengthened governance, marine reserves, ecosystem management and strengthened marine biodiversity. Publically funded buybacks for public goods issues address under-supply and are a Pigovian subsidy accounting for external benefits and free riding, not a 'bad' subsidy (but might not necessarily be first-best policy). Privately financed buybacks are not a subsidy but instead institute a 'double dividend' Pigovian tax through the levy, which give an extra boost towards solving the commons problem. Care, especially through auction design and private financing (except with public goods and social issues), has to be given to limit problems of asymmetric information - adverse selection and 'lemons' and moral hazard. Truly effective buybacks with an objective other than outright distributional issues and transfer payments have to be strictly coupled with a broader management objective that addresses best use of common resources and public goods and the root causes of their misuse and economic inefficiency. Buybacks should not be implemented or evaluated as a policy instrument in isolation.

\section{Acknowledgements}

The results are not necessarily those of NOAA Fisheries. The author is grateful to discussions and paper authors at the 2004 international buyback workshop participants at the University of California San Diego, to the participants at the 2009 Brussels, Seas at Risk Conference, 'Towards Sustainable European Fisheries', and to countless fishers and fishery managers of the Pacific Fisheries Management Council (especially Dick Young and Pete Leipzig), who imparted a very real appreciation for second-best policy and for the practical realities of political economy and organizing and motivating people in fisheries conservation and management that are not captured by economic models. All errors and conclusions remain those of the author.

\section{References}

Athey, S., Levin, J. and Seira, E. (2004) Comparing Open and Sealed Bid Auctions: Theory and Evidence From Timber Auctions. Fondazione Eni Enrico Mattei, Milan, Italy.

Barlow, J., Rojas-Bracho, L., Muñoz-Piña, C. and Mesnick, S. (2010) Conservation of the Vaquita (Phocoena sinus) 
in the Northern Gulf of California, Mexico. Chapter 15. In: Handbook of Marine Fisheries Conservation and Management (eds R.Q. Grafton, R. Hilborn, D. Squires, M. Tait and M. Williams). Oxford University Press, Oxford, UK, pp. 205-214.

Barrett, S. (2003) Environment and Statecraft: The Strategy of Environmental Treaty-Making. Oxford University Press, Oxford, UK.

Bustic, V. and Bromley, D.W. (2006) Purchasing a Way of Life: Do Fisheries Buyout Programs Work? Working paper, Department of Agricultural and Applied Economics, University of Madison, Wisconsin.

Campbell, H. (1989) Fishery buy-back programs and economic welfare. Australian Journal of Agricultural Economics 33, 20-31.

Campbell, H. and Lindner, R.K. (1990) The production of fishing effort and the economic performance of license limitation programs. Land Economics 66, 56-67.

Clark, C.W., Munro, G. and Sumaila, U. (2005) Subsidies, buybacks, and sustainable fisheries. Journal of Environmental Economics and Management 50, 47-58.

Clark, C.W., Munro, G. and Sumaila, U. (2007) Buyback subsidies, the time consistency problem and the ITQ alternative. Land Economics 83, 50-58.

Cueff, J.C. (2007) A case study of fishing vessel capacity management public buy-out schemes: community experience through the multi-annual guidance programmes and ways forward. Chapter 5. In: Fisheries Buybacks (eds R. Curtis and D. Squires). Wiley-Blackwell, Ames, IA., pp. 75-80.

Cunningham, S. and Greboval, D. (2001) Managing Fishing Capacity: A Review of Policy and Technical Issues. FAO Fisheries Technical Paper No. 409, Rome.

Curtis, R. and Squires, D. (2007) Fisheries Buybacks. Blackwell Publishers, Ames, IA.

Fox, K., Grafton, R.Q., Kompas, T. and Che, T. (2007) Capacity reduction and productivity: a case study of the Australian south east trawl fishery. Chapter 4. In: Fisheries Buybacks (eds R. Curtis and D. Squires). WileyBlackwell, Ames, IA., pp. 67-74.

GAO (US Government Accounting Office) (2001) Commercial fisheries: the effectiveness of fishing buyback programs can be improved. Testimony before the Subcommittee on Fisheries Conservation, Wildlife, and Oceans, Committee on Resources, U.S. House of Representatives, 10 May 2001. Available at: http:// www.gao.gov/new.items/d01699t.pdf. (last accessed 24 March 2010.)

Grafton, R.Q. and Nelson, H. (2007) The effects of buyback programs in the British Columbia salmon fishery. Chapter 12. In: Fisheries Buybacks (eds R. Curtis and D. Squires). Wiley-Blackwell, Ames, IA., pp. 191-202.

Groves, T. and Squires, D. (2007) Lessons from fisheries buybacks. Chapter 2. In: Fisheries Buybacks (eds R. Curtis and D. Squires). Wiley-Blackwell, Ames, IA.
Guyader, O., Berthou, P. and Daurès, F. (2007) Decommissioning schemes and capacity adjustment: a preliminary analysis of the French experience. Chapter 7. In: Fisheries Buybacks (eds R. Curtis and D. Squires). Wiley-Blackwell, Ames, IA., pp. 105-132.

Hallman, B., Barrett, S., Clarke, R.P., Joseph, J. and Squires, D. (2010) Limited access in transnational tuna fisheries. Chapter 12. In: Conservation and Management of Transnational Tuna Fisheries (eds R. Allen, J. Joseph and D. Squires). Wiley-Blackwell, Ames, IA., pp. 195-214.

Hannesson, R. (2007a) Buyback programs for fishing vessels in Norway. Chapter 11. In: Fisheries Buybacks (eds R. Curtis and D. Squires). Wiley-Blackwell, Ames, IA., pp. 55-66.

Hannesson, R. (2007b) Do buyback programs make sense?. Chapter 3. In: Fisheries Buybacks (eds R. Curtis and D. Squires). Wiley-Blackwell, Ames, IA., pp. 177190.

Holland, D., Gudmundsson, E. and Gates, J. (1999) Do fishing vessel buyback programs work: a survey of the evidence. Marine Policy 23, 47-69.

Kirkley, J. and Squires, D. (1988) A limited information approach for determining capital stock and investment in a fishery. Fishery Bulletin 86, 339-349.

Kirkley, J., Walden, J. and Waters, J. (2007) Buyback programs and industry restructuring in fisheries. Chapter 15. In: Fisheries Buybacks (eds R. Curtis and D. Squires). Wiley-Blackwell, Ames, IA., pp. 227-238.

Kitts, A., Thunberg, E. and Robertson, J. (2001) Willingness to participate and bids in a fishing vessel buyout program: a case study of New England groundfish. Marine Resource Economics 15, 221-232.

Klemperer, P. (2004) Auctions: Theory and Practice. Princeton University. Available at: http://www.paulklemperer. org/.

Kuronuma, Y. (1997) Japan: Part II. An economic theory behind the Japanese coastal fisheries management policy on fishing rights in relation to the license system for off-shore and distant-water fisheries. In: Towards Sustainable Fisheries: Issue Papers. Organisation for Economic Co-operation and Development, Paris, France.

Latacz-Lohmann, U. and Schilizzi, S. (2005) Auctions for Conservation Contracts: A Review of the Theoretical and Empirical Literature. Report to the Scottish Executive Environment and Rural Affairs Department, October, Edinburgh.

Lindebo, E. and Vestergaard, N. (2007) Vessel decommissioning in Danish fisheries. Chapter 6. In: Fisheries Buybacks (eds R. Curtis and D. Squires). Wiley-Blackwell, Ames, IA., pp. 81-104.

Martell, S., Walters, C. and Sumaila, R. (2009) Industryfunded fishing license reduction good for profits and conservation. Fish and Fisheries 10, 1-12.

Mas-Colell, A., Whinston, M. and Green, J. (1995) Microeconomic Theory. Oxford University Press, Oxford. 
Milgrom, P. (2004) Putting Auction Theory to Work. Cambridge University Press, Cambridge.

Nautilus Consultants (1997) The Economic Evaluation of the Fishing Boats (Decommissioning) Schemes. Nautilus Consultants, Edinburgh, UK.

Newby, J., Goday, P. and Elliston, L. (2004) Structural Adjustment in Australian Fisheries. Report prepared for the Fisheries Resources Research Fund, ABARE eReport 04.17, Canberra, Australia.

Niesten, E. and Gjertsen, H. (2009) Incentives in Marine Conservation Approaches: Comparing Buyouts, Incentive Agreements, and Alternative Livelihoods. Conservation International, Washington, DC.

Organization for Economic Cooperation and Development (OECD) (2009) Reducing Fishing Capacity: Best Practices for Decommissioning Schemes. OECD, Paris, France.

Read, A.G. and Buck, E.H. (1997) Commercial Fishing: Economic Aid and Capacity Reduction. CRS Report for Congress. Congressional Research Service, Washington, DC. Available at: http://www.cnie.org/NLE/CRSreports/ Marine/mar-24.cfm.

Riechers, R., Griffin, W. and Woodward, R. (2007) The Texas inshore bay and bait license buyback program. Chapter 14. In: Fisheries Buybacks (eds R. Curtis and D. Squires). Wiley-Blackwell, Ames, IA., pp. 215-226.

Spagnolo, M. (2007) The decommissioning scheme for the Italian clam fishery: a case of success. Chapter 8. In: Fisheries Buybacks (eds R. Curtis and D. Squires). WileyBlackwell, Ames, IA., pp. 133-144.

Spagnolo, M. and Sabatella, R. (2007a) Driftnets buyback program: a case of institutional failure. Chapter 9. In: Fisheries Buybacks (eds R. Curtis and D. Squires). WileyBlackwell, Ames, IA., pp. 145-156.

Spagnolo, M. and Sabatella, E. (2007b) The impact of the EU buyback scheme on the Italian fleet: The Northern and Central Adriatic sea bottom trawlers case. Chapter

\section{Appendix: Asymmetric information, moral hazard, adverse selection and lemons}

Asymmetric information arises when parties to a transaction hold differing quantities and quality of information. The principal-agent problem arises when a principal, such as the buyback authority, compensates an agent, such as the vessel owner, for performing certain acts that are useful to the principal and costly to the vessel owner, and where there are elements of the performance that are costly to observe.

Moral hazard is a special case of the problem of asymmetric information, whereby the actions of one party to a transaction are unobservable, so that one party in a transaction has more information than
10. In: Fisheries Buybacks (eds R. Curtis and D. Squires). Wiley-Blackwell, Ames, IA., pp. 157-176.

Squires, D., Joseph, J. and Groves, T. (2006) Buybacks in transnational fisheries. Pacific Economic Bulletin 21, $63-$ 74 .

Squires, D., Groves, T., Grafton, Q., Curtis, R., Joseph, J. and Allen, R. (2010) Fisheries buybacks. Chapter 39. In: Handbook of Marine Fisheries Conservation and Management (eds R.Q. Grafton, R. Hilborn, D. Squires, M. Tait and M. Williams). Oxford University Press, Oxford, UK.

Sun, C.-H. (2007) Effectiveness of vessel buyback programs on the offshore fishery in Taiwan. Chapter 13. In: Fisheries Buybacks (eds R. Curtis and D. Squires). WileyBlackwell, Ames, IA., pp. 203-214.

Thunberg, E., Kitts, A. and Walden, J. (2007) A case study of New England groundfish fishing capacity reduction. Chapter 16. In: Fisheries Buybacks (eds R. Curtis and D. Squires). Wiley-Blackwell, Ames, IA., pp. 239-248.

Vestergaard, N. (2010) Principal-agent problems in fisheries. Chapter 42. In: Handbook of Marine Fisheries Conservation and Management (eds R.Q. Grafton, R. Hilborn, D. Squires, M. Tait and M. Williams). Oxford University Press, Oxford., pp. 563-571.

Weninger, Q. and McConnell, K.E. (2000) Buyback programs in commercial fisheries: efficiency versus transfers. Canadian Journal of Economics 33, 394-412.

Whitford, A. (2007) Designing markets: why competitive bidding and auctions in government often fail to deliver. The Policy Studies Journals 35, 61-85.

Woodrow, M. (1998) A case study of fisheries reduction programs during the Northern Cod Moratorium. Ocean and Coastal Management 39, 105-118.

World Bank (2004) Saving Fish and Fisheries: Towards Sustainable and Equitable Governance of the Global Fishing Sector. Report No. 29090-GLB, Agriculture and Rural Development Department. World Bank, Washington, DC.

another (Mas-Colell et al. 1995). There are incentives to evade contract requirements or to 'cheat'. Moral hazard occurs when a party shielded from risk may behave differently than it would behave if it was fully exposed to the risk. The party that is insulated from risk generally has more information about its actions and intentions than the party paying for the negative consequences of the risk. More broadly, moral hazard occurs when the party with more information about its actions or intentions has a tendency or incentive to behave inappropriately from the perspective of the party with less information.

Adverse selection arises when an informed individual's trading decisions depend on that individual's privately held information in a manner that 
adversely affects uninformed market participants (Mas-Colell et al. 1995). In a vessel-buyback market, a vessel owner is more likely to decide to sell the vessel when that owner knows that the vessel is not very good, when it is often what is called a 'lemon'. In short, there is an incentive for owners of 'lemons' to sell. When adverse selection is present, uninformed traders, such as buyback agencies, may be more wary of any informed trader wishing to sell and the agency's willingness to pay for the vessel or permit offered may be lower.

There are 'good' used vessels and 'defective' used vessels ('lemons'), but because of asymmetric infor- mation about the vessel, the seller knows much more about the problems of the vessel than does the buyer. Accordingly, the buyer's best guess for a given vessel is that the vessel is of average quality; as such, the buyer will be willing only to pay for a vessel of known average quality. This means that the owner of a 'good' used vessel will be unable to get a high enough price to make selling that 'vessel' worthwhile. Therefore, owners of 'good' vessels are less likely to place their vessels on the buyback market. This is sometimes summarized as the bad driving out the good' in the market. 